\title{
AN ATTEMPT TO CONTROL SCHISTOSOMIASIS MANSONI IN AN ENDEMIC AREA BY THE USE OF HYCANTHONE AS CHEMOTHERA- PEUTIC AGENT *
}

\author{
J. C. Bina ** and Aluizio Prata **
}

\begin{abstract}
Hycanthone in a single dose of $3.3 \mathrm{mg} / \mathrm{kg}$ of body weight was used to treat mansoni schistosomiasis in 597 persons $(83 \%)$ of the population of the endemic vilage of Canabrava. Ninety two patients received a $2^{\text {nd }}$ course 14 months later. There was one death an the $2^{\text {nd }}$ treatment. The cure rate after one stool examination was smaller after the $2^{\text {nd }}$ treatment in comparison with the first one.

Re-infections did not occur imediately after the treatment. Three years later the prevalence of persons passing eggs through one stool examination was $19 \%$ compared to the $46.3 \%$ before the treatment. Adults are more resistant to the re-infections than younger.
\end{abstract}

\section{INTRODUCTION}

After large experience with Hycanthone in hospitals and out-patient clinics (5, $6,10,11)$ this drug was then used for treat. ment of schistosomiasis in a low endemic area (3) The results above obtained and other not yet published indicated that the drug could be used to attemptt the control of the infection in a small locality as described below.

\section{MATERIAL AND METHODS}

The population of Canabrava, county of Mirangaba (Bahia) distant about $500 \mathrm{~km}$ northwest of Salvador, was treated with Hycanthone.

The small village of Canabrava is 10cated within the semiarid regions of northeastern Brazil known as "caatinga". Most of the local inhabitants are employed in agriculture, without any type of irrigation.
There is a small lake where the water for use of people and animals is taken. During the dry season the water remains only in ponds. There is no water supply, sanitation or electricity in the village. The streets are unpaved.

Biomphalaria glabrata is the snail intermediate host found in the area

Canabrava had at the beginning of this study, 718 inhabitants, being 349 males and 369 females accordng to the age distribution found in Table 1.

Seventy three per cent of the above population was born in the area. Stool examination by Kato's method was performed in 655 persons, with a rate of $46,3 \%$ of positive results although some of them had been tested few days after the use of the drug. Graphic I shows the prevalence rates according to age groups. The infection rate was $48 \%$ for females and $44 \%$ for males.

Fundagão Gonçalo Moniz and Núcleo de Pesquisa da Bahia, supported by Conselho Nacional de Pesquisas, Superintendência do Desenvolvimento do Nordeste and World Health Organization.

* Assistant of the Department of Tropical Medicine, University of Bahia.

*** Professor of Tropical Medicine, University of Bahia and Fundação Gonçalo Moniz. Presently at the University of Brasilia.

Submitted to publication on 6-20-1974. 
Table 1 - Distribution of the population in Canabrava according to age groups.

\begin{tabular}{cc}
\hline Age (Years) & Person \\
& No \\
$<1$ & 15 \\
1 & 22 \\
2 & 21 \\
3 & 26 \\
4 & 33 \\
5 & 30 \\
6 & 18 \\
7 & 30 \\
8 & 15 \\
9 & 20 \\
10 & 31 \\
11 & 13 \\
12 & 16 \\
13 & 21 \\
14 & 7 \\
$15-19$ & 73 \\
$20-24$ & 74 \\
$25-29$ & 51 \\
$30-34$ & 45 \\
$35-39$ & 17 \\
$40-44$ & 34 \\
$45-49$ & 20 \\
$50-54$ & 28 \\
$55-59$ & 14 \\
Over 59 & 32 \\
$?$ & 12 \\
\hline TOTAL & 718 \\
\hline
\end{tabular}

Skin tests were made in 378 persons, 160 of them in children under 12 years old. These tests revealed $67 \%$ of positives, being $66 \%$ of males and $67 \%$ of females.

The combination of stool examinations and skin tests raised the infection rate to 82 percent for the whole population (Graphic I).

The right lobule of the liver was not palpable in $41 \%$ of the patients. In the remaining the liver was palpable as follows: in $46 \%$ during deep breathing; in $4 \%$ at the coastal ridge; in $8 \%$ from one to four cm under the coastal ridge; and in $1 \%$ from four to seven $\mathrm{cm}$ under the coastal ridge. The left lobule of the liver was not palpable in $44 \%$ of the patients. However it was palpable in the remaining patients as follows: in 29\% during deep breathing; in $15 \%$ at the coastal ridge; in $17 \%$ from one to four $\mathrm{cm}$ under the coastal ridge; in $8 \%$ from four to seven $\mathrm{cm}$ under the coastal ridge; and in $0,4 \%$ over $12 \mathrm{~cm}$. under the coastal ridge. The left lobule of the liver was proeminent in four patients. The liver was soft in $31 \%$ of the cases, slightly hard in $54 \%$ and hard in $15 \%$ of the subjects. In five cases the liver had a nodular surface.

The spleen was not palpable in $96 \%$ of the patients. In $3,2 \%$ of the persons the spleen was palpable just at the end of a deep breathing. Only in two cases large spleens were observed.

According to the above data only two patients were classified as hepatosplenic cases while the remaining ones were considered as hepatintestinal. Schistosomiasis in this area does not show the severity observed in other villages situated in the same region such as Caatinga do Moura and Taquarendi.

In June 1969 Hycanthone was given, under medical supervision, by intramuscular route to 597 patients $(83 \%$ of the

\section{GRAPHIC - : \\ PREVALENCE RATES OF SCHISTOSOMIASIS MEASURED BY STOOL EXAMINATION SKIN TEST OR BOTH, ACCORDING TO AGE GROUPS}

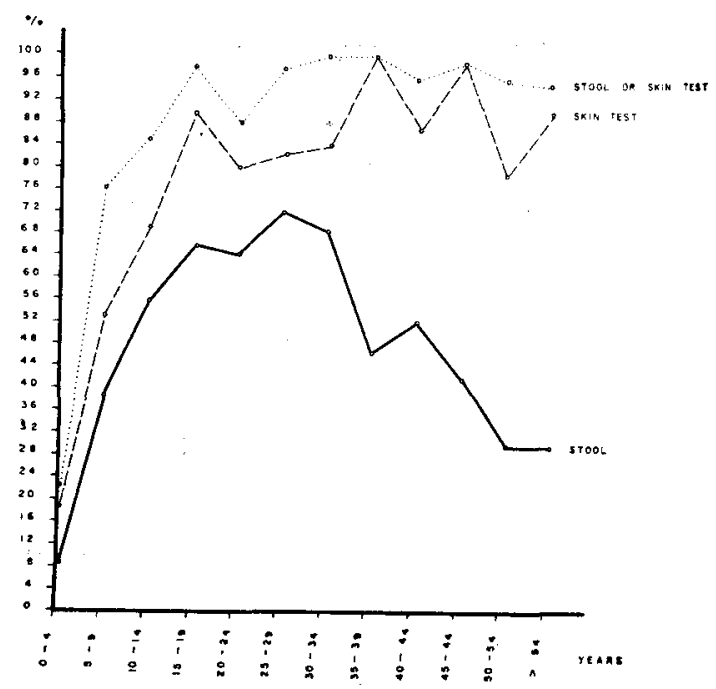


whole population), at the doses of $3.3 \mathrm{mg}$ per $/ \mathrm{kg}$. The age groups of the treated patients are found in Table 2. There was 307 males and 205 females.

Children under two years of age, the pregnant women, two patients with paralysis, two with cardiac failure, two old persons with bronchial asthma were excluded. $\mathbf{7 \%}$ of patients with schistosomiasis were not treated.

No restriction to any ordinary habits of the population was imposed during or after the treatment.

The Kato's method for stool examinations was used for evaluation purposes beginning with two examinations after four months of the treatment and the other examination later. An average of five stool examinations was performed for each patient during the period of 4 to 14 months after the treatment.

Table 2 - Distribution of the patients treated with Hycanthone according to age groups.

$\begin{array}{cc}\text { Age (Years) } & \text { Treated } \\ 2 & 16 \\ 3 & 24 \\ 4 & 32 \\ 5 & 29 \\ 6 & 18 \\ 7 & 29 \\ 8 & 14 \\ 9 & 20 \\ 10 & 26 \\ 11 & 13 \\ 12 & 13 \\ 13 & 20 \\ 14 & 7 \\ 15-19 & 63 \\ 20-24 & 57 \\ 25-29 & 36 \\ 30-34 & 42 \\ 35-39 & 13 \\ 40-44 & 30 \\ 45-49 & 19 \\ 50-54 & 26 \\ 55-59 & 12 \\ \text { Over 59 } & 29 \\ ? & 6 \\ \text { TOTAL } & 597\end{array}$

At 7 August 1970, 92 positive patients were re-treated with the same dose of $\mathrm{Hy}$ canthone. These patients had the following ages: 48 between 2 to 10 years; 32 between 11 and 19 years and 12 over 19 years old. The stools of 90 patients were examined two months after the re-treatment.

A final stool examination was made at August 1972 in 496 persons found in the area from the population examined in 1969.

\section{RESULTS}

The first treatment was given to whole group within the period of two days by only one person. The drug was well tolerated and the toxic reactions and side effects, both frequency and intensity, were similar to those observed in Varzea Nova (3).

After the first post-treatment stool examination, only four subjects were positive for $S$. mansoni eggs. Additional four positive cases were found in the second stool examination; the third examination showed 108 positive subjects; the fourth 25; and the fifth 11. After all, these five stool examinations eggs were found in 152 patients ( 80 males and 72 females). In other words, $25,5 \%$ of patients were still passing eggs in stools. Table 3 shows the presence of eggs in the stools after the treatment, according to the age.

Positive stool examinations are less frequent in older age groups.

During the second treatment scheme, a six years old patient presented incoercible vomiting and developed jaundice. Taken to the hospital in a near town the patient died seven days later the Hycanthone injection. The probable cause of death was toxic hepatitis although autopsy was not performed. This infortunate occurrence resulted in the interruption of the use of $\mathrm{Hy}$ canthone in successive re-treatments.

The only stool examinations made for evaluation of the re-treatment revealed 21 positive subjects or $23 \%$ of the re-treated patients. Of those 21 patients, 10 were 3 to 10 years old, 9 between 11 to 19 and 2 over 19.

The final stool examination at 1972 showed that 96 patients were passing eggs in 496 examined $(19 \%)$. This percentage is 
Table 3 - Evaluation of treatment of schistosomiasis with Hycanthone according to age group

\section{Age (Years)}

Positive After
Treatment

\begin{tabular}{cr}
2 & 3 \\
3 & 5 \\
4 & 8 \\
5 & 8 \\
6 & 10 \\
7 & 10 \\
8 & 7 \\
9 & 11 \\
10 & 17 \\
11 & 6 \\
12 & 6 \\
13 & 14 \\
14 & 2 \\
$15-19$ & 21 \\
$20-24$ & 6 \\
$25-29$ & 7 \\
$30-34$ & 4 \\
$35-39$ & 2 \\
$40-44$ & 1 \\
$45-49$ & 0 \\
$50-54$ & 1 \\
$55-59$ & 1 \\
Over 60 & 2 \\
$?$ & 0 \\
TOTAL & 152 \\
& \\
\hline
\end{tabular}

less than the primitive $(46,3 \%)$ found at 1969.

Although the pregnant women were not treated, three normal children were born in the follow-up nine months after the treatment from mothers that ignored they were pregnant.

Graphic II shows the relationships between the presence of eggs of $S$. mansoni in the stools before and after treatment according to age groups.

\section{COMMENTS}

In areas where the infection has low prevalence and the disease is of little weight, the treatment of the patients is of great value as it was demonstrated in Varzea Nova (3). In areas where the snail hosts are present and the spreading of the infection depends only of the presence of infected persons, seem to us that treatment of the infected subjects is the best way for preventing the expansion of the disease.

About $80 \%$ of the patients usually do not accomplish the treatment with the antimonial salts (13) mainly because the multiple injections. A drug like Hycanthone, used in a single dose and with a cure rate of $90 \%$ opened new hopes. Unfortunately, now we know that Hycanthone also produces fatalities and this is the most important limitation for its use in campaign schemes. In Canabrava we did not feel encouradged to continue our program of repeated treatments of the re-infected persons as it was planed for control of schistosomiasis in this area.

A relatively high percentage of positives $(23 \%)$ found after the second injection of Hycanthone in contrast with $0,7 \%$ obtained in the first use the drug, suggests the possibility of acquired resistance as has been experimentally demonstrated by Rogers and Bueding (12). This aspect deserves further investigation.

GRAPHIC- 11

PREVALENCE OF SCHISTOSOMIASIS MEASURED

BY THE PRESENCE OF EGGS IN STOOLS, BEFORE AND

AFTER TREATMENT, ACCORDING TO AGE GROUPS

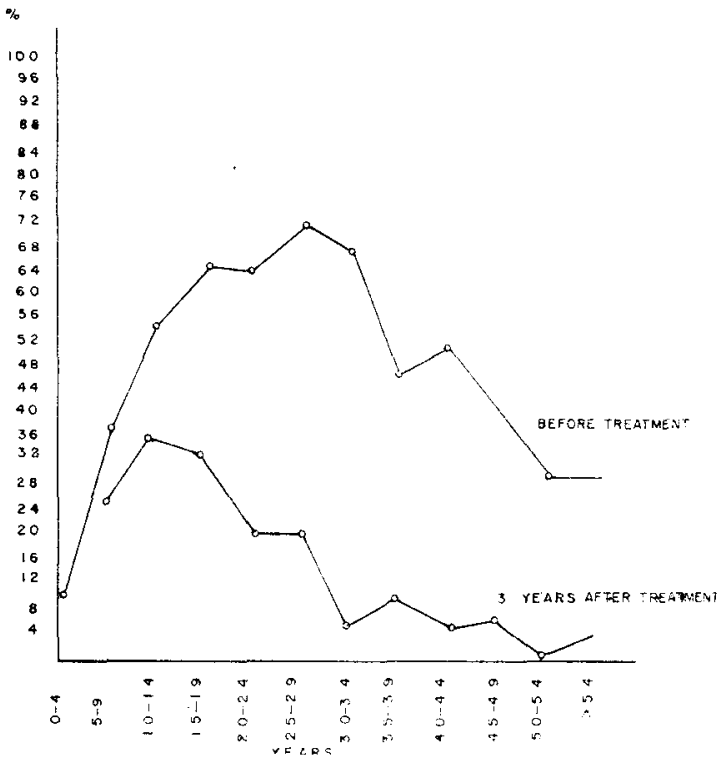


According to Vlanna Martins (9) mass treatment can be defined as "the simultaneous or near so treatment of large number of persons representing a great proportion of a given population".

The effects of mass treatment either on the reduction of the prevalence rates or on the prevention of the severe clinical cases, has not yet been assessed. Our results suggest that just after the treatment the resistance to the new infections seems to be very great. Re-infections do not occur immediatly after treatment. Although the first evaluation of the cure rates were made only after 4 months, the initial two stool examinations revealed only 8 positive cases; the reduced prevalence rates can be kept as such for long periods $(4,4)$. Graphic II shows that the frequency curve of schistosomiasis in Canabrava mado of through stool examinations, has similar shape than others found in different regions $(2,7,8)$ with just one little difference: in Canabrava there is a slight deviation of the peak of the curve towards the right side. After treatment the peak of the curve is clearly deviated to the left. The percentage of stool poitive is less in any age group after the treatment even if a period of three years is considered. However, it is important to emphasize that from 14 years of age on, the curve deflects rapidly indicating that after this age the individuals seem to have not been so easily re-infected. If this is the case, we could admit that treatment would antecipate a natural tendency for expontaneous cure which follows the age progression.

As there was very few patients with portal-hypertension at Canabrava, we cannot assess the role of the treatment on the prevention of the severe clinical forms.

\section{SUMMARY}

Hycanthone na dose de $3,3 \mathrm{mg} / \mathrm{kg}$ de peso corporal foi usado no tratamento de $597(83 \%)$ pessoas da população da vila de Canabrava, onde a esquistossomose é endêmica. Noventa e dois pacientes foram retratados após 14 meses. Houve um óbito após o retratamento. $011^{\circ}$ exame de fezes revelou $0,7 \%$ de resultados positivos após o tratamento e $23 \%$ após o retratamento.

As reinfcções não ocorrem imediatamente após o tratamento. Três anos após o tratamento inicial a prevalência de um exame de fezes positivo na pourulação era de $19 \%$ em comparação com $46 \%$ antes do tratamento. Os adultos são mais resistentes à reinfecção.

\section{REFERENCES}

1. ARFAA, F., FARATMANDIAN \& SOLEIMANI, M. Evaluation of the effect of mass - chemotherapy as a method of the control of Bilharziasis. Iran, First African Symposium on Bilharziasis, 1969.

2. BARBOSA, F. A. S. Morbidade na esquistossomose. Recife, 1965. 180 pp. Thesis.

3. BINA, J. C. \& PRATA, A. Hycanthone no tratamento da esquistossomose em uma área rural com baixo índice de transmissão da doença Gaz. méd. Bahia, 70:, 127-130, 1970.
4. EL-GINDY, S. M. \& BAQUIR, H. A progre sive campaign for bilharziasis control First African Symposium on Bilharziasis, 1969.

5. FIGUEIREDO, J. F. M. \& PRATA, A. Eficácia do Hycanthone no tratamento da esquistossomose mansoni. Gaz. méd. Bahia, 69: 16-19, 1969.

6. FIGUEIREDO, J. F. M., CARVALHO, E. A., CARVALHO, J. S., MACEDO, V., DINIZ GONCALVES, H. J. \& MONTENEGRO, M. A. Tolerabilidade do $\mathrm{Hy}-$ canthone e resultados preliminares quanto à sua eficácia no tratamento da esquistoszomose mansoni. Gaz. méd. Bahia, 68: 124-131, 1968. 
7. FAROOQ, M., NIELSON, J.. SAMAAN, S.A., MALLAH M. B. \& ALTAM, A. A. The Epidemiology of Schistosoma haematobium and $S$. mansoni infections. 2. Prevalence of Bilharziasis in Relation to Personal tributes and Habits. Bull. Wld. Hith. Org. 35: 293-318, 1966.

8. KLOETZEL, K. Aspectos epidemiolćgicos da esquistossomose mansonica. São Paulo, 1962. 119 pp. Thesis.

9. MARTINS, A. V. Plano de tratamento em massa. In. Esquistossomose mansoni no Brasil, 1953.

10. PORTO, G. \& PRATA, A. Tratamento da esquistossomose pelo Hycanthone, na infância. Gaz. méd. Bahia, 71: 103-109, 1971.

11. PORTO, G., PRATA, A. \& OLIVEIRA, V. Hycanthone na esquistossome aguda. Gaz. méd. Bahia, 71: 110-112, 1971.

12. ROGERS, S. H. \& BUEDING, E. Hycanthone resistance: Development in Schistosoma mansoni. Science 172: 1057-1060, 1971.

13. SHERIF, A. F. Mass suppressive treat. ment of Bilharziasis "A new trend for ntrol of the disease". Proceedings of the Ist. National Symposium on Bilhariasis, Cairo, 1964. 